\title{
Traumatic Peritentorial Subdural Hematomas: A Study of 32 Cases
}

\section{Travmatik Peritentoriyal Subdural Hematomlar: 32 Olguluk Bir Çalışma}

Satoru TAKEUCHI ${ }^{1}$, Yoshio TAKASATO ${ }^{2}$, Hiroyuki MASAOKA² ${ }^{2}$ Takanori HAYAKAWA ${ }^{2}$, Hiroshi YATSUSHIGE ${ }^{2}$, Kimihiro NAGATANI ${ }^{1}$, Naoki OTANI ${ }^{1}$, Hideo OSADA ${ }^{1}$, Kojiro WADA ${ }^{1}$, Hiroshi NAWASHIRO ${ }^{1}$

${ }^{1}$ National Defense Medical College, Department of Neurosurgery, Saitama, Japan

${ }^{2}$ National Hospital Organization Disaster Medical Center, Department of Neurosurgery, Tokyo, Japan

Correspondence address: Satoru TAKEUCHI / E-mail: drne776@ndmc.ac.jp

\begin{abstract}
AIM: This study aimed to investigate the clinicoradiological features in patients with traumatic peritentorial subdural hematomas (SDHs).

MATERIAL and METHODS: We retrospectively reviewed the clinical and radiological findings, management criteria, and outcomes in 32 patients with peritentorial SDHs. The outcomes were classified as favorable (good recovery or moderate disability) or poor (severe disability, vegetative state, or death).

RESULTS: Of the 32 patients, 19 were male and 13 were female. The patients' ages ranged from 10-92 years (mean age, 60.9 years). Coagulopathies were observed in 23 patients. Twenty-four patients presented with associated intracranial lesions. Eighteen patients had favorable outcomes and 14 had poor outcomes. All patients were treated conservatively. The presence of coagulopathy $(p=0.024)$ and presence of convexity SDH $(p=0.008)$ correlated with the outcome.

CONCLUSION: The patients with traumatic peritentorial SDHs were predominantly male and relatively elderly, and had a high incidence of coagulopathy, associated intracranial lesions (especially falx SDHs), a high rate of impact in the occipital or frontal regions, and a low incidence of skull fractures. The factors that were correlated with outcome in patients receiving conservative therapy were the presence of coagulopathy and the presence of convexity SDH.
\end{abstract}

KEYWORDS: Head injury, Peritentorial, Subdural hematoma, Outcome

öz

AMAÇ: Bu çalışma, travmatik peritentoriyal subdural hematomları (SDH'ler) olan hastalarda klinikoradyolojiközellikleri araştırmayı amaçlamıştır. YÖNTEM ve GEREÇLER: Peritentoriyal SDH bulunan 32 hastada klinik ve radyolojik bulgular, takip kriterleri ve sonuçlar retrospektif olarak değerlendirilmiştir. Sonuçlar olumlu (iyi iyileşme veya orta derecede maluliyet) veya zayıf (şiddetli maluliyet, vejetatif durum veya ölüm) olarak sınıflandırılmıştır.

BULGULAR: Otuz iki hastanın 19'i erkek, 13'ü kadındır. Hastaların yaşları 10-92 yıl aralığındadır (ortalama yaş 60,9 yıl). Koagülopatiler 23 hastada görülmüştür. Yirmi dört hasta ilişkili intrakraniyal lezyonlarla gelmiştir. On sekiz hastanın sonucu olumlu ve 14'ünün olumsuz bulunmuştur. Tüm hastalar konservatif olarak tedavi edilmiştir. Koagülopati varlığı $(p=0,024)$ ve konvekste $S D H$ varlığı $(p=0,008)$ sonuçla korelasyon göstermiştir. SONUÇ: Travmatik peritentoriyal SDH bulunan hastalar temel olarak erkek ve nispeten yaşı olup koagülopati ve ilişkili intrakraniyal lezyon (özellikle falx SDH için) insidansı yüksek, oksipital veya frontal bölgelere darbe alma oranı yüksek ve kafatası kırığı insidansı düşük bulunmuştur. Konservatif tedavi alan hastalarda sonuçla ilişkili faktörler arasında koagülopati varlığı ve konveksitede SDH varlığı yer almıştır.

ANAHTAR SÖZCÜKLER: Kafa travması, Peritentoriyal, Subdural hematom, Sonuç

\section{INTRODUCTION}

Traumatic subdural hematomas (SDHs) are most frequently located over the convexity of the brain (1), and peritentorial SDHs are rare (2-5). Because of their rarity, few reports of either single cases or small case series have been published in the English literature (2-5). We have experienced 32 cases of traumatic peritentorial SDHs. We investigated the association between the clinicoradiological findings and outcomes in these patients. This study provides the first analysis of significant prognostic factors for traumatic peritentorial SDHs.

\section{MATERIAL and METHODS}

From 1995 to 2010, 5,066 patients with head trauma were hospitalized at our hospital. The present study focused on 32 patients $(0.6 \%)$ with traumatic peritentorial SDHs. Only those patients with clear evidence of trauma as the primary etiology were included in this analysis. We retrospectively reviewed the patients' clinical and radiological findings, management and outcomes. We defined associated coagulopathy as follows: thrombocytopenia (platelet count $<1.0 \times 10^{5} / \mathrm{mm}^{3}$ ), a prolonged international normalized ratio (INR) (normal range, 0.92-1.10), or an increased activated partial thromboplastin 
time (APTT) (normal range, 24-36 seconds). The patient's level of consciousness and outcome were assessed using the Glasgow Coma Scale (GCS) at admission and the Glasgow Outcome Scale (GOS) 6 months after injury. We classified GOS scores into favorable (good recovery or moderate disability) or poor (severe disability, vegetative state, or death) outcomes.

The Mann-Whitney $U$ test and Fisher's exact test were used to explore the univariate differences in the clinicoradiological features between outcome groups. Values of $p<0.05$ were considered to be statistically significant. All statistical analyses were performed using the SPSS software package version 11.0 for Windows.

\section{RESULTS}

The clinical and radiological findings, outcomes, and results of the analysis related to the outcomes are summarized in Table I. Of the 32 patients, 19 were male (59\%) and 13 were female (41\%). The patients' ages ranged from 10-92 years (mean age, 60.9 years). The mean platelet count was $1.9 \times 10^{5}$ / $\mathrm{mm}^{3}$, the mean INR was 1.64, and the mean APTT was 34.6 seconds. Coagulopathies were observed in 23 patients (72\%). Seven patients (22\%) were injured after drinking alcohol. An antiplatelet agent and anticoagulant were administered to one patient, and an anticoagulant alone was administered to another patient. Four patients suffered from hypovolemic shock.

The mechanisms of injury were falls in 22 patients (69\%) and traffic accidents in 10 patients (31\%). The mean admission GCS score was 11.9. The sites of impact were the occipital area in 12 patients (38\%), the frontal area in five patients, the temporal area in five patients, the parietal area in three patients, and the face in one patient. There was no evidence of head impact in six patients (19\%). Skull fractures were revealed in 10 patients (31\%). Eight patients (25\%) presented with isolated peritentorial SDH, and 24 (75\%) presented with associated intracranial lesions. The associated intracranial lesions were falx SDH in 15 patients, convexity SDH in 10 patients, cerebral contusions in 10 patients, epidural hematomas in four patients, and subarachnoid hemorrhage $(\mathrm{SAH})$ in 11 patients. Three patients (9\%) had brain atrophy. However, cerebral venous thrombosis was not observed in any patients. Additionally, none of the patients developed acute hydrocephalus.

All patients were treated conservatively for peritentorial SDHs, although six patients underwent surgical procedures for associated intracranial lesions. The outcomes included good recovery in seven patients (22\%), moderate disability in 11 patients (34\%), severe disability in four patients (13\%), vegetative state in one patient (3\%), and death in nine patients (28\%). The incidence of a poor outcome was 44\% (14/32).

We compared the variables between the favorable and poor outcome groups to identify potential prognostic factors of peritentorial SDHs. Convexity SDHs were observed in two (11\%) of the 18 patients in favorable outcome group, whereas they were observed in 8 (57\%) of the 14 patients in the poor outcome group. Coagulopathies were observed in 10 (56\%) of the 18 patients in the favorable outcome group, whereas they were observed in 13 (93\%) of the 14 patients in the poor outcome group. The mean platelet count was $2.1 \times 10^{5} / \mathrm{mm}^{3}$, the mean INR was 1.16, and the mean APTT was 30.8 seconds

Table I: Prognostic Factors Related to Outcome in Patients with Traumatic Peritentorial Subdural Hematomas

\begin{tabular}{|c|c|c|c|c|}
\hline Variable & $\begin{array}{l}\text { All patients } \\
(n=32)\end{array}$ & $\begin{array}{l}\text { Favorable outcome } \\
\qquad(n=18)\end{array}$ & $\begin{array}{l}\text { Poor outcome } \\
(n=14)\end{array}$ & p value \\
\hline Age (years)* & $60.9 \pm 22.6$ & $63.7 \pm 21.7$ & $57.3 \pm 23.9$ & 0.357 \\
\hline Sex (male/female) ( $n$ ) & $19 / 13$ & $11 / 7$ & $8 / 6$ & 0.553 \\
\hline Coagulopathy (n) & 23 & 10 & 13 & 0.024 \\
\hline Alcohol drinking $(n)$ & 7 & 3 & 4 & 0.351 \\
\hline Medication with antiplatelet and/or anticoagulant (n) & 2 & 0 & 2 & 0.183 \\
\hline Hypovolemic shock (n) & 4 & 2 & 2 & 0.597 \\
\hline Mechanism (fall/traffic accident) ( $n$ ) & $22 / 10$ & $14 / 4$ & $8 / 6$ & 0.194 \\
\hline GCS score* & $11.9 \pm 3.9$ & $13.1 \pm 2.8$ & $10.4 \pm 4.6$ & 0.071 \\
\hline Skull fracture $(n)$ & 10 & 4 & 6 & 0.194 \\
\hline \multicolumn{5}{|l|}{ Associated intracranial lesions ( $n$ ) } \\
\hline Falx SDH & 15 & 10 & 5 & 0.225 \\
\hline Convexity SDH & 10 & 2 & 8 & 0.008 \\
\hline Contusion & 10 & 8 & 2 & 0.073 \\
\hline $\mathrm{EDH}$ & 4 & 1 & 3 & 0.210 \\
\hline SAH & 11 & 6 & 5 & 0.590 \\
\hline Brain atrophy (n) & 3 & 1 & 2 & 0.404 \\
\hline
\end{tabular}

Abbreviations: $\mathbf{E D H}=$ epidural hematoma; $\mathbf{G C S}=$ Glasgow Coma Scale; $\mathbf{S A H}=$ subarachnoid hemorrhage; $\mathbf{S D H}=$ subdural hematoma. ${ }^{*}$ Mean \pm SD 
in the favorable outcome group. However, the mean platelet count was $1.6 \times 10^{5} / \mathrm{mm}^{3}$, the mean INR was 2.31 , and the mean APTT was 39.9 seconds in the poor outcome group.

The factors identified as being correlated with outcome were the presence of coagulopathy $(p=0.024)$ and the presence of convexity SDH $(p=0.008)$. There were no significant differences in the outcomes in relation to the other factors.

\section{Representative case}

A 69-year-old male who had been admitted to our hospital for chronic renal failure and myelodysplastic syndrome fell out of his bed. His GCS score on examination was 13, which was the same as before the trauma. No other neurological deficit was detected. A brain computed tomography (CT) scan revealed a peritentorial SDH (Figure $1 \mathrm{~A}-\mathrm{C}$ ). A peripheral blood count revealed a hemoglobin level of $6.5 \mathrm{~g} / \mathrm{dL}$, hematocrit of $18.9 \%$, and a platelet count of $16,000 / \mathrm{mm}^{3}$. Platelet and red blood cell transfusions were administered, and the patient was observed carefully for peritentorial SDH. Magnetic resonance imaging (MRI) was performed the day after the trauma to determine the location of the hematoma, which was confirmed to be on the superior surface of the tentorium cerebelli (Figure 2A,B). A repeat CT scan showed resolution of the hematoma 1 month after the trauma (Figure 1D). However, the patient died as a result of renal failure 2 months after the trauma.

\section{DISCUSSION}

Our series of patients with traumatic peritentorial SDHs displayed several interesting features, including male predominance, a relatively old mean age, high rates of coagulopathy, a high frequency of associated intracranial lesions (especially falx SDHs), a high incidence of impact in the occipital or frontal regions, and a low incidence of skull fractures.

Although the mechanism(s) responsible for traumatic peritentorial SDH remains unclear, tearing of vessels adjacent to the tentorium (the bridging veins to the straight sinus or tentorial sinus) caused by linear brain acceleration during trauma is currently regarded as the most likely possibility (3-5). In our series, the findings of 1) a high incidence of impact in the occipital or frontal regions and 2) a low incidence of skull fractures (31\%) may support this mechanism. We also investigated the presence of brain atrophy because it can be hypothesized that vessels adjacent to the tentorium tend to tear when the brain is more mobile. Nevertheless, unexpectedly, only three patients (9\%) had brain atrophy. We therefore hypothesize that associated intracranial lesions might mask the presence of brain atrophy in some patients.

A diagnosis of peritentorial $\mathrm{SDH}$ can be readily made by CT. Lau et al. reported typical CT findings of peritentorial collection as follows; 1) a sheet-like collection, meaning the
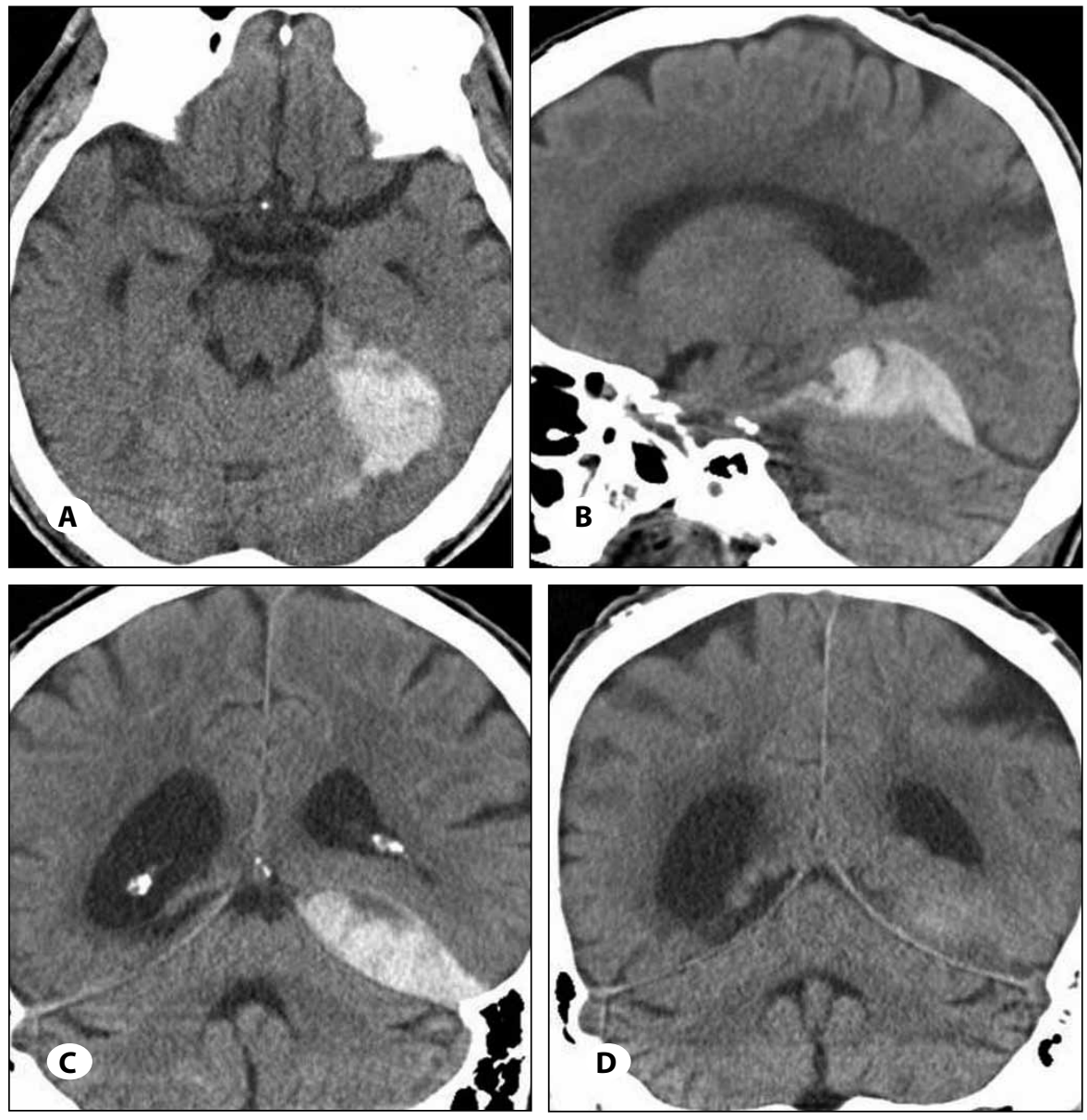

Figure 1: A brain CT scan revealed a peritentorial $\mathrm{SDH}$, but was unable to determine the relationship between the hematoma and the tentorium cerebelli. (A) Axial view, (B) sagittal view, (C) coronal view. (D) A repeat CT scan (coronal view) showed resolution of the hematoma 1 month after the trauma. 

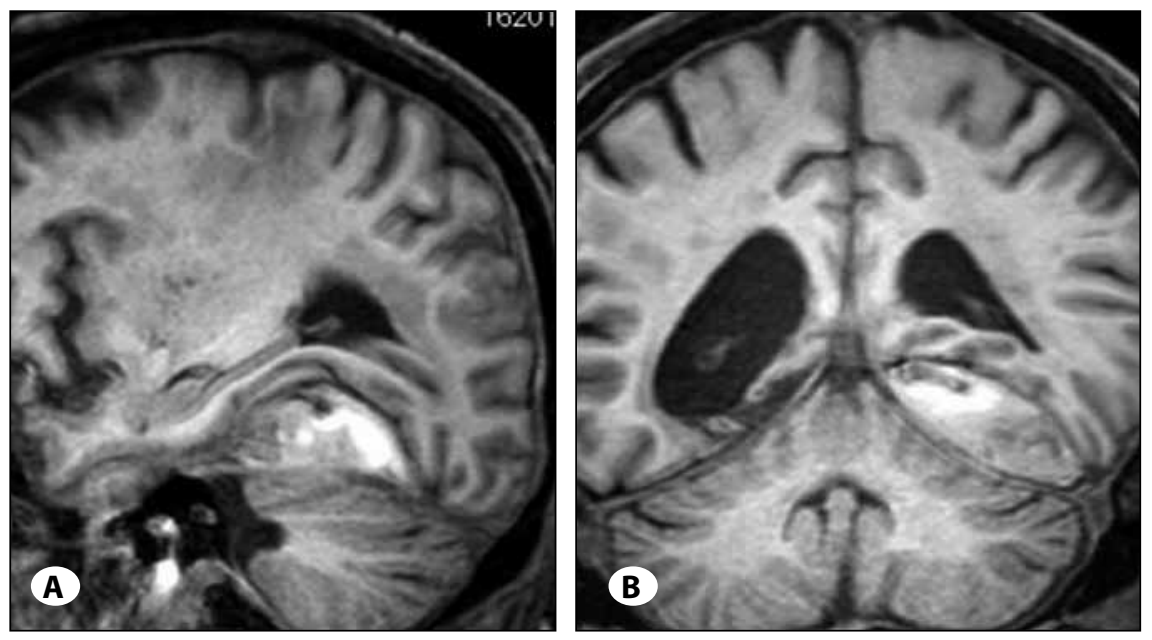

Figure 2: Brain T1-weighted magnetic resonance images obtained the day after the trauma confirmed the presence of a hematoma located in the superior surface of the tentorium cerebelli. (A) Sagittal view, (B) coronal view.

appearance of a sheet-like area of increased attenuation with a sloping, hazy, lateral margin conforming to the general configuration of the tentorium, with a well-defined medial margin corresponding to the free edge of the tentorium, and 2) the trigone sign, referring to the rotation of the trigone (4). MRI can provide further information about the presence of blood in the vicinity of the tentorium cerebelli, such as: 1) subdural collection of blood above the tentorium cerebelli; 2) subdural collection of blood on the inferior surface of the cerebellum; 3) posttraumatic subarachnoid hemorrhage in that area; and 4) collection of blood within the dissected dura layers (6). Confirmation of the location of the hematoma is necessary to allow it to be safely accessed if surgery is required.

The optimal management strategy for peritentorial SDHs is unclear. Conservative therapy may be preferred if the patient's neurological condition is stable, or if any accompanying diseases contraindicate surgery. However, we believe that surgery should be performed in cases with large hematomas or rapidly deteriorating levels of consciousness. All of the patients in our series received conservative therapy for peritentorial SDHs because of their thin hematoma size or poor general condition. Further studies are needed to clarify whether surgery can improve the outcome.

Many prognostic factors for common traumatic SDHs (convexity) have been identified in previous studies, including age, the GCS score, hematoma size, presence of a midline shift, and the presence of $\operatorname{SAH}(2,7)$, but there has been no analysis of the prognostic factors associated with traumatic peritentorial SDHs. We found that the presence of coagulopathy and the presence of convexity SDH were correlated with the outcome.

There were some limitations associated with this study. First, its retrospective nature meant that it was subject to observation and assessment bias. Second, the number of patients in the series was small, which reduced the statistical power, and thus increased the chance of type- 2 errors. The small sample size also did not allow for a multivariate analysis to further investigate the validity of the prognostic factors. In addition, all patients received conservative therapies, and none of the patients in our series underwent surgery for their traumatic peritentorial SDHs. Further studies including cases with larger lesions are needed to evaluate the prognosis of the entire spectrum of traumatic peritentorial SDHs. However, despite its limitations, the results of the current study will help to predict the prognosis in patients with peritentorial SDHs.

\section{REFERENCES}

1. Bullock M R, Chesnut R, Ghajar J, Gordon D, Hartl R, Newell DW, Servadei F, Walters BC, Wilberger JE: Surgical Management of Traumatic Brain Injury Author Group: Surgical management of acute subdural hematomas. Neurosurgery 58:16-24, 2006

2. Domenicucci M, Strzelecki J W, Delfini R: Acute posttraumatic subdural hematomas: "Intradural" computed tomographic appearance as a favorable prognostic factor. Neurosurgery 42: 51-55, 1998

3. Govaert $P$, Calliauw L, Vanhaesebrouck P, Martens F, Barrilari A: On the management of neonatal tentorial damage. Eight case reports and a review of the literature. Acta Neurochir (Wien) 106: 52-64, 1990

4. Lau L S, Pike J W: The computed tomographic findings of peritentorial subdural hemorrhage. Radiology 146: 699-701, 1983

5. Matsumoto K, Houri T, Yamaki T, Ueda S: Traumatic acute subdural hematoma localized on the superior surface of the tentorium cerebelli--two case reports. Neurol Med Chir (Tokyo) 36: 377-379, 1996

6. Moskała M, Polak J, Moskała A, Kleinrok K, Zawiliński J: Haematoma of the tentorium cerebelli - new pathology or new prognostic factor in neurotraumatology? A preliminary report. Neurol Neurochir Pol 41:234-240, 2007

7. Servadei F, Nasi M T, Giuliani G, Cremonini AM, Cenni P, Zappi D, Taylor GS: CT prognostic factors in acute subdural haematomas: The value of the 'worst' CT scan. Br J Neurosurg 14: $110-116,2000$ 